\title{
Stakeholder Engagement and Organizational Performance: A Case of Kenya Power and Lighting Company, Eldoret Branch, Uasin-Gishu County - Kenya
}

\author{
Nkobe D. Kenyoru \\ Assistant Lecturer, Department of Accounting and Finance, \\ School of Business and Economics, Moi University, Eldoret. \\ Sammy Kimutai Chumba \\ Department of Accounting and Finance, \\ School of Business and Economics, Moi University, Eldoret. \\ Gideon Chumba \\ Administrator, Trans-Nzoia County, \\ Shadrack Rotich \\ Part-time Lecturer - various Universities in Uasin-Gishu County
}

\begin{abstract}
The effects of stakeholder involvement in daily running of organizations remain unclear on their performance leading to the current study. The study specifically investigated employee investment, performance management systems, employee participation in decision, product customization, customer recognition, and customer relationship management on firm performance. Stakeholder theory was the basis of the study with a descriptive research design employed on a target population of 718. Stratified random sampling was used in selecting a sample size of 215 employees and customers. Data was collected using self-administered closed-ended questionnaires and analyzed using both descriptive and inferential statistics. Pearson product moment correlation and multiple regression models were employed with findings indicating customer recognition $(\beta 5=0.441, P$ Value $=0.000)$, employee decision making involvement $(\beta 3=0.234, P$ Value $=0.04)$, customer relationship management $(\beta 6=0.2, P$ Value $=0.000)$, employee investment $(\beta 1=0.145, P$ Value $=0.05)$, performance management system $(\beta 2=0.143, P$ Value $=0.04)$ and product customization $(\beta 4=0.084, P$ Value $=0.000)$ all having positive effect on firm performance significant at 0.05 . The overall regression result indicated an $\mathrm{R} 2=0.762$ with an implication that $76.2 \%$ of the changes in organizational performance is as a result of stakeholder involvement in decision making process. The research therefore concluded that both the customer and employee involvement strategies contributed significantly to the performance of the organizations with the customer recognition indicating more effect on the performance of the organization. The research recommended that the two stakeholders be an integral part in decision making process for better performance.
\end{abstract}

\section{INTRODUCTION}

Stakeholder Engagement Strategy is a very important tool in the organizational management. It refers to strategic managerial activity which is concerned with the planning and controlling 
of the whole organizational environment, that is, internal and external environments (Pandey, 2005) Pandey further stated that Stakeholder Engagement Strategy is not a unique body of knowledge of its own, and draws heavily on economics for its theoretical concepts even today. It is of immense interest to both academicians and practicing managers. A good Stakeholder Engagement Strategy mechanism should foresee inefficiencies and enable organizations take steps in preventing them from happening. It should also ensure that high quality and reasonable profit is achieved. In order for this system to be achieved organizations people inquisitive and hard working at all times and be ready to make any changes in the organizations if need be (Ammenberg, 2001).

Some research has analyzed specific factors external to the firm that drive the adoption of environmental strategies such as regulation and competitive forces (Fang, 2002; Berry and Dennis, 2000; Delery, \& Shaw, 2001), and pressure from nongovernmental organizations (Landry, 2004). Other research has looked at the characteristics of the firm to explain the adoption of 'beyond compliance' strategies. This includes the influence of organizational context and design and organizational learning. Other analyses have focused on the individual or managerial level, examining the effects of leadership values and managerial attitudes (Laplume, 2008). According to Maslach (2001), the biggest challenge and opportunity for success is to change the way a company thinks about the environment. It must be seen as a business issue: what benefits does the environment bring the company and its customers How far should organizations go in abiding by stakeholders' interests? According to stakeholder theory, strategy should take into account, if not be built around, stakeholder interests. Such an approach is not only wrong-headed, it's impracticable. Companies can account for any stakeholder considerations they view as important through their Balanced Scorecard and strategy map and hold performance to them without compromising strategy or their ability to adjust it.

In line with Stakeholder Engagement Strategy, organizational management approach to Organization Performance is essential. Traditionally, management education has not been concerned with environmental but with the running of an on-going enterprise. Time is not an immediate concern. Change is minimal and protracted, and hence can be thoroughly programmed and progressively integrated. The work places of such enterprises are bounded by traditional hierarchies, lines of authority, centralized control and repetitive, assembly-line type jobs. Unfortunately, this traditional corporate management approach breaks down where Organization Performance is concerned. Consequently, new management relationships are required, which tend to cut across the normal flow of authority and responsibility and radiate outside of the functional unit (McKinley, 2005).

The stakeholder theory propose that stakeholders including governments, regulators, customers, competitors, community and environmental interest groups, and industry associations impose coercive and normative pressures on firms. However, the way in which managers perceive and act upon these pressures depends upon many factors which including their track record of environmental performance, the competitive position of the parent company and the organizational structure of the company. Beyond providing a framework of how stakeholder pressures influence plants' Organization Performance practices, various measures are proposed to quantify institutional pressures, key plant-level and parent company-level characteristics and plant level Organization Performance.

To be tested empirically, this comprehensive framework of the drivers of the adoption of Organization Performance practices necessitates an empirical approach that combines both existing publicly available databases, as well as original data from a survey questionnaire at the plant level. Publicly available databases can provide information on 'objective pressures' while 
the survey questionnaire can give information about the perception of pressure from the Stakeholder Engagement Strategy stand the actions taken in response. The combination of these sources of information allows the evaluation of the difference between objective and perceived pressures and the resulting adoption of Organization Performance practices.

Nevertheless, studies on stakeholder engagement and how it affects organizational performance are limited particularly in the emerging economies like Kenya. in additional, studies that in developed countries cannot be generalized in developing countries due to different geographic set up, different organizational structure and economic differences. As such this study attempted to address the gap in the existing literature and assess the effect of stakeholder engagement on organizational performance.

\section{Employee Investment}

\section{LITERATURE REVIEW}

Employee investments in company stock could offer many advantages and disadvantages to the employer. Stock ownership could motivate employees to work harder. On the other hand, if company stock under-performs the stock market, worker motivation might be adversely affected, and in extreme situations, management could face legal liability as plan fiduciaries (Mitu, 2007). Rauh (2003) investigated this hypothesis and finds some support for it (though the magnitudes are not large). Perhaps not surprisingly, employers do not offer this as their primary reason for supporting employee ownership

H01: employee investment has no significant effect on organizational performance

\section{Performance Management}

Employee Performance Management is a process for establishing a shared workforce understanding about what is to be achieved at an organization level. It is about aligning the organizational objectives with the employees' agreed measures, skills, competency requirements, development plans and the delivery of results. The emphasis is on improvement, learning and development in order to achieve the overall business strategy and to create a high performance workforce (Gunter, 2010). Ngugi, (2003) viewed the performance management process as consisting of various sub processes: strategy development, budgeting target setting, execution/forecasting, performance measurement, performance review and incentive compensation. These integrated sub processes create the performance-driven behavior of employees that is needed to become and stay a high-performance organization.

H02: Performance management systems have no significant effect on organizational performance

\section{Participative Decision-Making}

Employee involvement in decision making, sometimes referred to as participative decisionmaking (PDM) is concerned with shared decision making in the work situation (Mitchell, 2007). According to McKinley, (2005), PDM is a special form of delegation in which the subordinate gain greater control, greater freedom of choice with respect to bridging the communication gap between the management and the workers. It refers to the degree of employee's involvement in a firm's strategic planning activities. Organizations benefit from the perceived motivational influences of employees in PDM. When employees participate in the decision-making process, they improve understanding and perceptions among colleagues and superiors, and enhance personnel value in the organization (Huang, 2005). 
When participative decision-making takes place in a team setting, it can cause many disadvantages. These can be anything from social pressures to conform to group domination, where one person takes control of the group and urges everyone to follow their standpoints. With ideas coming from many people, time can be an issue. The meeting might end and good ideas go unheard. Possible negative outcomep0s of PDM are high costs, inefficiency, indecisiveness and incompetence (Mitu, 2007).

H03: employee participation in decision making has no significant effect on organizational performance

\section{Product Customization}

Landry, (2004) points out that the trend towards product customization that can be observed nowadays is the result of many changes in the business environment. These have enforced many suppliers to revise their production strategies and management concepts. Mass production provides a mass market with goods at a consistent quality and affordable prices.

Peters, (2009) speaks about a feedback loop that has characterized the interplay between customers and suppliers. This feedback loop has strengthened standardized products, mass production techniques and large, homogeneous markets. As a result, it was not necessary to offer several product options. For instance, Henry Ford promised his customers to receive any car colour they would like to have, as long as it was black.

H04: Product customization has no significant effect on organizational performance

\section{Customer Relationship Management}

Successful development, implementation, use and support of customer relationship management systems can provide a significant advantage to the user, but often there are obstacles that obstruct the user from using the system to its full potential. Instances of a CRM attempting to contain a large, complex group of data can become cumbersome and difficult to understand for ill-trained users (Seijts, 2006). Engaged employees are more committed to the organization, they are less likely to leave for other opportunities because they like what they are doing, they like where they are and they like people they are with. Fully engaged employees tell others about the organization and are more likely to refer good candidates. They have a sense of pride and ownership in the organization. They are more productive and contribute more significantly to the organizations success. Employees become fully engaged after basic workplace needs are fulfilled accord management system (Naumann, 2005).

H05: Customer recognition has no significant effect on organizational performance

\section{RESEARCH METHODOLOGY}

The research design employed in this study was descriptive research design, generally qualitative in nature. The study was carried out at Kenya power and lighting Company, Eldoret Branch. Eldoret is one of the major towns in this country of Kenya. Eldoret Town is in Rift Valley Province, The target population of this study comprised all employee of Kenya power limited Eldoret There are 718 employees in KPLC North rift (HR department Database, 2012) hence the study will select 30\% from each department providing a sample size of 215 employees The researcher distributed the questionnaires randomly, which was clarified and explained adequately to the respondents. Pearson correlation moment was used to show the interrelation ship within the variables as well as relationship between the dependent variable and independent variable. Multiple regression were used to test the hypotheses of the study.

$y=\beta 0+\beta 1 \times 1+\beta 2 \times 2+\beta 3 \times 3+\beta 4 \times 4+\beta 5 \times 5+\beta 6 \times 6+\varepsilon$ 
Where;

$\mathrm{Y}=$ dependent variable (performance of organization)

$\mathrm{X} 1=$ Employee investment

$\mathrm{X} 2$ = Performance management system

$\mathrm{X} 3=$ Employee involvement in decision making

$\mathrm{X} 4=$ Product customization

$\mathrm{X} 5=$ Customer recognition

X6=Customer Relationship management

$\beta 1$...... $\beta 6=$ Parameters of the model

$\varepsilon=$ term error

\section{Correlation Results}

\section{FINDINGS}

The Pearson's correlation describes the linear relationship between two variables. A linear relationship is one where an increase in one variable is associated with an increase and vice versa. The study used correlation analysis to understand the magnitude of the relationship. It also assists in understanding the building block of the linear relationship.

Table 1: Correlation Statistics

\begin{tabular}{|c|c|c|c|c|c|c|}
\hline $\begin{array}{c}\text { Performanc } \\
\text { e }\end{array}$ & $\begin{array}{c}\text { Employee } \\
\text { investmen } \\
t\end{array}$ & $\begin{array}{c}\text { Performanc } \\
\text { e } \\
\text { managemen } \\
\text { t system }\end{array}$ & $\begin{array}{c}\text { Employee } \\
\text { involvemen } \\
\text { t in } \\
\text { decision } \\
\text { making }\end{array}$ & $\begin{array}{c}\text { Product } \\
\text { customizatio } \\
n\end{array}$ & $\begin{array}{c}\text { Customer } \\
\text { recognitio } \\
\text { n }\end{array}$ & $\begin{array}{c}\text { Customer } \\
\text { Relationshi } \\
\text { p } \\
\text { managemen } \\
\text { t }\end{array}$ \\
\hline
\end{tabular}

\begin{tabular}{|c|c|c|c|c|c|c|c|}
\hline Performance & 1 & & & & & & \\
\hline $\begin{array}{l}\text { Employee } \\
\text { investment }\end{array}$ & $.472 * *$ & 1 & & & & & \\
\hline $\begin{array}{l}\text { Performance } \\
\text { management } \\
\text { system }\end{array}$ & $.752 * *$ & $.436^{* *}$ & 1 & & & & \\
\hline $\begin{array}{l}\text { Employee } \\
\text { involvement } \\
\text { in decision } \\
\text { making }\end{array}$ & $.429 *$ & .123 & $.471 * *$ & 1 & & & \\
\hline $\begin{array}{l}\text { Product } \\
\text { customizatio } \\
\text { n }\end{array}$ & $.227 * *$ & .417 & $.553 * *$ & .712 & 1 & & \\
\hline $\begin{array}{l}\text { Customer } \\
\text { recognition }\end{array}$ & $.329 *$ & $.118^{* *}$ & .089 & $.321 *$ & .411 & 1 & \\
\hline $\begin{array}{l}\text { Customer } \\
\text { Relationship } \\
\text { management }\end{array}$ & $.227 * *$ & $.714 * *$ & $.112 * *$ & $.921 *$ & .612 & $.192 *$ & 1 \\
\hline
\end{tabular}


Results from Table 4.2 reveals that Performance management system had the highest Pearson correlation value of 0.752 in relation to organizational performance, thus Performance management system had the highest positive relationship with organizational performance of 75.2 percent, the relationship was significant at 0.001. Employee investment had the second highest relationship with organizational performance at reported by Pearson correlation value of 0.472 significant at 0.000 , suggesting that there is enough evidence to infer that there is positive relationship between Employee investment and organizational performance.

Regarding Employee involvement in decision making results in table 4.8 reported the Employee involvement in decision making scored a Pearson correlation value of 0.429 significant at 0.01 level of significance implying that employee involvement in decision making had positive and significant relationship with firm performance of 42.9 percent. Most correlation results indicate that Product customization, Customer recognition, Customer Relationship management had positive relationship with organization performance as shown by Pearson correlation values of $0.227,0.329$ and 0.227 respectively significant at 0.05 level of significance

\section{Regression Results}

The study further investigated extent of the effect of each independent variable on firm performance. Multiple regression analysis was used to show the effect.

Table 4.9 Coefficient of Estimates (Testing the Study Hypothesis)

\begin{tabular}{|c|c|c|c|c|c|}
\hline & $\begin{array}{l}\text { Unstandardized } \\
\text { Coefficients }\end{array}$ & \multicolumn{3}{|c|}{ Standardized Coefficients } & \multirow[b]{2}{*}{ Sig. } \\
\hline & B & Std. Error & Beta & $\mathbf{t}$ & \\
\hline (Constant) & -0.05 & 0.085 & & -0.593 & 0.004 \\
\hline $\begin{array}{l}\text { Employee } \\
\text { investment }\end{array}$ & 0.296 & 0.139 & 0.145 & 2.129 & 0.005 \\
\hline $\begin{array}{l}\text { Performance } \\
\text { management } \\
\text { system }\end{array}$ & 0.51 & 0.247 & 0.143 & 2.059 & 0.04 \\
\hline $\begin{array}{l}\text { Employee } \\
\text { involvement in } \\
\text { decision } \\
\text { making }\end{array}$ & 0.841 & 0.311 & 0.234 & 2.708 & 0.000 \\
\hline $\begin{array}{l}\text { Product } \\
\text { customization }\end{array}$ & 0.211 & 0.128 & 0.084 & 1.131 & 0.000 \\
\hline $\begin{array}{l}\text { Customer } \\
\text { recognition }\end{array}$ & 0.492 & 0.059 & 0.441 & 8.304 & 0.000 \\
\hline $\begin{array}{l}\text { Customer } \\
\text { Relationship } \\
\text { management }\end{array}$ & 0.355 & 0.122 & 0.2 & 2.919 & 0.000 \\
\hline R squared & & 0.762 & & & \\
\hline Adjusted R Squ & red & 0.751 & & & \\
\hline ANOVA (F Val & & 24.511 & & & \\
\hline P Value & & 0.000 & & & \\
\hline
\end{tabular}

Dependent Variable: organization performance

Results from Table 4.9 illustrated model summary of the study which comprises of coefficient of determination ( $\mathrm{R}$ squared), R squared was recorded to be 0.762 , suggesting that 76.2 percent of the total variation of the dependent variable is explained by joint contribution of employee investment, performance management system, employee involvement in decision 
making, product customization, customer recognition and customer relationship management. Adjusted R squared was recorded to be 0.751 it attempts to correct R squared to more closely reflect the goodness of fit of the model in the population.

Next is ANOVA results. This table indicates that the regression model predicts the outcome variable significantly well. As evident of $F$ ratio 24.511 with $\mathrm{p}$ value of $0.000<0.05$. This indicates the statistical significance of the regression model that was applied. Here, $\mathrm{P}<0.0005$ which is less than 0.05 and indicates that, overall, the model applied is significantly good enough in predicting the outcome of organizational performance. It basically tells us that regression equation is statistically significant in explaining a portion of the variability in the dependent variable from variability in the independent variables.

The table below provides Coefficients, for each predictor variable. This provides us with the information necessary to predict firm performance.

Results from table below indicated that employee investment had coefficient estimate ( $\beta 1$ ) of 0.145 with $\mathrm{p}$ value of 0.035 which was less than 0.05 level of significance, hence the study concluded that there is significant relationship between employee investment contribution and organizational performance. This implies that employee investment positively affect organizational performance with 0.145 units, increase in employee investment with one unit increase organizational performance with 0.145 units.

More results in table 4.4.3 reported that performance management system recorded a coefficient of estimate ( $\beta 2$ ) of 0.143 with a p value of 0.004 which was less than $\alpha=0.05$, hence we therefore inferred that there is significant relationship between performance management system on organizational performance. Thus, Performance management system positively affect organizational performance, increase in performance management system with one unit increases organizational performance with 0.143 units.

Employee involvement in decision making had coefficient estimate ( $\beta 3$ ) of 0.234 significant at 0.05 level of significance, consequently, we concluded that there is significant relationship between Employee involvements in decision making on organizational performance. This suggests that there is enough evidence that Employee involvement in decision making positively affect organizational performance. Increase in Employee involvement in decision making with one unit increase firm performance with 0.234 . This is depicted in table 4.9

Product customization had coefficient estimate ( $\beta 4$ ) of 0.0 .084 significant at 0.05 (level of significance) consequently; we concluded that there is significant relationship between Product customization on organizational performance. This suggests that there is enough evidence that product customization positively affect organizational performance. Increase in Product customization with one unit increase organizational performance with 0.0.084 unit.

The study also showed a model summary which showed that 76.2 percent of the total variation of the dependent variable is explained by joint contribution of employee investment, performance management system, employee involvement in decision making, product customization, customer recognition and customer relationship management. The ANOVA results also indicated that regression model predicts the outcome variable significantly. As shown by the F ratio of 24.511 with $\mathrm{p}$ value of $0.000<0.05$. This indicated that the statistical significance of the regression model that was applied. Here, $p<0.0005$ which is less than 0.05 and indicates that, overall, the model applied is significantly good enough in predicting the 
outcome of organizational performance. It basically tells us that regression equation is statistically significant in explaining a portion of the variability in the dependent variable from variability in the independent variables and from this; the predicted regression coefficients were given. The study showed that employee investment had coefficient estimate $\beta 1=0.145$ with $p$ value of 0.035 which was less than 0.05 level of significance; hence there is a significant relationship between employee investment contribution and organizational performance. This implies that employee investment positively affects organizational performance such that, with 0.145 units increase in employee investment there is one unit increase organizational performance. Also, performance management system recorded a coefficient of estimate $\beta 2=$ 0.143 with a $\mathrm{p}$ value of 0.004 which was less than $\alpha=0.05$ and thus we infer that there is a significant relationship between performance management system on organizational performance. As a result, performance management system positively affects organizational performance such that, a unit increase in performance management system results in an increase in organizational performance with 0.143 units. Employee involvement in decision making had coefficient estimate $\beta 3=0.234$ which was significant at $\alpha=0.05$, consequently, there is a significant relationship between employee involvement in decision making on organizational performance. This suggests that employee involvement in decision making positively affects organizational performance such that with every unit increase in employee involvement in decision making there is a resultant increase in firm performance by upto $23.4 \%$. The study also showed that product customization had coefficient estimate $\beta 4=$ 0.0.084 which was significant at $\alpha=0.05$. Consequently; there is a significant relationship between product customization on organizational performance. This suggests that product customization positively affects organizational performance such that a unit increase in product customization results in an increase in organizational performance by approximately $8.4 \%$.

\section{CONCLUSION}

The encouragement of employee investment in a company as an employee engagement strategy affects the performance of the KPLC. When there are avenues through which employees can invest in the companies they are working for, the companies will improve their performances. Companies that have developed forums where employees and other interested persons can contribute and express their views on matters of the company will be in a position to enhance its operations and performance by considering the views expressed. When employees are encouraged to invest in the company feel that they are a part and parcel of the company and the input into the company is enhanced.

Performance management systems have an impact on the performance of organizations. Implementing strategies that make companies set goals for the employees will have a hard working lot of employees that try to accomplish their goals. The performance management systems where employees are equipped with the skills and tools to take charge of their work responsibilities will result in a group of effective and productive and effective employees. The implementation of performance management system that drives focus and transparency is vital to the success of today's leading organisations because individual employees are aligned to performance contracts with departmental business plans to achieve the overall company vision, mission and strategies.

By encouraging employees to participate in decision making the performance of the KPLC is not affected. Where there is stiff competition, organizations usually consider the views of the employees in making decisions. KPLC hardly involve the employees in the decision making process of the organization. This is because the company enjoys the monopoly of the power generation and distribution in Kenya and hence it is characterized by 'autocratic' decisions. 
The product customization as a customer engagement strategy influences the performance of KPLC. The organization has implemented a number of customization strategies that has resulted in an increase the company sales. The company has created methods in which customers can get the company's services with convenient. The company has liaised with other companies to help ease the process of the payment of bills. Some of these companies include telecommunication companies such as Safaricom MPESA services and Airtel Money. The company has also expanded its customer base by distributing electricity to many parts of the country. The KPLC has also ensured that there is no or minimal electricity interruption in companies and regions where the company gets a lot of sales. These strategies have made the company to realise good performance.

Customer recognition as a customer retention strategy does not have a significant impact on the performance of KPLC. The company does not see the need to recognize customers because it enjoys exclusive possession and control of supply of electricity in Kenya and does not need to implement customer retention strategies. The company also does not see the need of rewarding loyalty to its customers and improving their morale. The performance of the company cannot be significantly affected even if the customer recognition strategies are not employed.

Customer relationship management as a customer engagement strategy has no significant impact on the performance of KPLC. The company should implement customer relationship management strategies with a lot of reluctance because of the business environment characterized by high demand that company is operating in. The performance of the KPLC will still remain unaffected even if the CRM strategies are not implemented.

\section{Recommendations of the Study}

The study made the following research recommendations based on the factors that were computed as contributing more significantly to the effects of stakeholder engagement strategy on organizational performance. The KPLC should encourage employees to invest in the company as an employee engagement strategy so that they can contribute and confidently express their views on matters of the company and enhance the implementation of performance management system that will make employees drive focus and transparency that is vital to the success of today's leading organisations. KPLC should implement strategies where customers and employees can participate in decision making process of the performance and customer recognition where it rewarding loyalty of customers and excellent work of employees.

\section{Suggestions for further Studies}

This is a case study research of KPLC branch in Eldoret in Kenya and thus the results of the study may not generalize the state of affairs other regions of the country. The research suggests that other studies to be carried out in other regions. The topic of the study should be based on the effects of stakeholder engagement strategy on organizational performance. Further the study was only carried on employees only and since the study involves all the stakeholders thus the study recommended the same study to be carried from the customer point of view and other stakeholders.

\section{References}

Ammenberg, J. (2001). How Do Standardized Organization Performance Systems

Andrews, Richard N. L. et al. (2003). Organization Performance Systems: Do They Improve Performance? Final Report of the National Database on Organization Performance Systems Pilot Project. Chapel Hill, NC: Department of Public Policy, UNC-Chapel Hill. Also on line at http://ndems.cas.unc.edu/ 
Attridge, M. (2009). Employee Work Engagement: Best Practices for Employers. Research Works: Partnership for Workplace Mental Health

Baum \& Oliver, (2001). Institutional linkages and organizational mortality. Administrative Science Quarterly, 36: 187-21.

Berry, M. and Dennis, R. (2000). Organization Performance in the Pharmaceutical Industry: Integrating Corporate Responsibility and Business Strategy. Environmental Quality Management 9(3):21-33.

Delery, J. \& Shaw, J. (2001) .The strategic management of people in work: review, synthesis and extension.

Research in Personnel and Human Resources Management, 20: 165-197.

DiMaggio, P. \& Powell, W. (2003). The iron cage revisited: Institutional isomorphism and collective rationality in organizational fields, American Sociological Review.

Fang, X. (2002). The movement of independent labor unions in Taiwan. Taiwan Society Studies, 13: 286-289.

Freeman, R., (2004). Strategic management: A stakeholder approach. Boston: Pitman Publishing.

Frooman, J., (2009). Stakeholder influence Strategy. Academy of Management Review, 24(2): 191-205.

Gilson, R. L., \& Harter, L. M. (2004). The Psychological Conditions of Meaningfulness, Safety and Availability and the Engagement of the Human Spirit at Work. Journal of Occupational and Organizational Psychology.

Gonrig, M. P. (2008). Customer loyalty and Employee Engagement: An Alignment for Value.

Gray, R., Kouhy, R., \& Lavers, S. (1995). Corporate social and environmental reporting: A review of the literature and a longitudinal study of UK disclosure, Accounting, Auditing \& Accountability Journal, 8(2):47-77.

Gunter B. Furnham A. (2010). Biographical and Climate Predictors of Job Satisfaction and Pride in Organisation. The Journal of Psychology.

Harter, J.K., Schmidt, F.L. \& Hayes, T.L. (2002) Business-Unit-Level Relationship

Holbeche, L., \& Springett, N. (2003). In Search of Meaning in the Workplace. Horsham,

Huang, I. C. \& Cheng F. Tsai. (2005). Stakeholders' responding to downsizing strategies: fromperspectives of stakeholder theory. Journal of Human Resource Management

Kahn, W. A. (1990). Psychological Conditions of Personal Engagement and Disengagement at

Landry, J. (2004). Downsizing in America: Reality, Causes, and Consequences. Harvard Business Review, 82 (2): 39.

Laplume, A. O., Sonpar, K., \& Litz, R.A. (2008). Stakeholder Theory: Reviewing a theory that moves us. Journal of Management, 34(6): 1152-1189.

Lu, C.D., Chiu, C.F. \& Chen, L. D. (2003). The impacts of economic globalization on the institution of labor unions in Taiwan. 2003 Annual conference of Taiwan Society Association. Taipei, Taiwan.

Maslach, C., Schaufeli, W. B., \& Leiter, M. P. (2001). Job Burnout. Annual Review of Psychology

Mathieu, J. E., \& Zajac, D. M. (1990) A Review and Meta-Analysis of the Antecedents, Correlates and Consequences of Organizational Commitment. Psychological Bulletin

Mckee-Ryan, F.M., \& Kinicki, A.J. (2002). Coping job loss: a life-facet perspective. International Review of Industrial and Organizational Psychology, 17: 1-29.

McKinley, W., Sanchez, C.M., \& Schick, A.G... (2005). Organizational downsizing: constraining, cloning, learning. Academy of Management Executive, 9(3): 32-44.

McKinley, W., Zhao, J., \& Rust, K. G. (2000). A socio-cognitive interpretation of organizational downsizing. Academy of Management Review, 25(1): 227-243.

Mendelow, R.J. and Lance, C.E. (2001) 'A Review and Synthesis of the Measurement Invariance Literature: Suggestions, Practices, and Recommendations for Organizational Research', Organization Research Methods, 12: 4-69.

Mitchell, R.K., Agle, B.R., \& Wood, D.J. (2007). Toward a theory of stakeholder identification and salience: defining the principle of who and what really counts. Academy of Management Review, 22: 853-886. 
Kenyoru, N. D., Chumba, S. K., Chumba, G., \& Rotich, S. (2015). Stakeholder Engagement and Organizational Performance: A Case of Kenya Power and Lighting Company, Eldoret Branch, Uasin-Gishu County - Kenya. Archives of Business Research, 3(2), 188-198.

Mitu, E.M. (2007) ‘Do "High Commitment” Human Resource Practices Affect Employee Commitment? A CrossLevel Analysis Using Hierarchical Linear Modeling',

Naumann, E. S., Bies, J.R., \& Martin, L.C... (2005). The EFFECTSs of organizational support and Justice during a Layoff. Academy of Management Journal, special issue: 89-95.

Ngugi, K. (2003). Employee Satisfaction, Employee Engagement, and Business Outcomes: A Meta-Analysis. Journal of Applied Psychology

Oliver, C., (2001). Strategic response to institutional processes. Academy of Management Review. 16:.145-179.

Oliver, C., (2007) .Sustainable competitive advantage: Combining institutional and resource-based views. Strategic Management Journal. 18(9): 697-713.

Peters, B.G. (2009). Institutional Theory in Political Science: The New- Institutionalism. London: Pinter Press.

Roberts, D. R., \& Davenport, T. O. (2002). Job Engagement: Why It's Important and How To Improve It. Wiley Periodicals, Inc,

Robinson D. Perryman S. Hayday S. (2004). The Drivers of Employee Engagement. IES Report 408. ISBN 185184 336 Roffey Park.

Rowley, T. (1997). Moving beyond dyadic ties: A network theory of stakeholder influences, Academy of Management Review, 22(4): 887-911.

Saks, A. M. (2006). Antecedents and Consequences of Employee Engagement. Journal of Managerial Psychology

Schaufeli, W. B., Bakker, A., \& Salanova, M. (2006). The Measurement of Work Engagement with a short questionnaire: A Cross-National Study. Educational and Psychological Measurement

Seijts, G. H., \& Crim, D. (2006). What Engages Employees the Most, or the Ten C's of Employee Engagement. Ivey Business Journal, March/April, 1-5. Work. Academy of Management Journal 